\title{
Yeni kaynaklar ıșığında yeni bir Rauf Yekta Bey biyografisi
}

\author{
Duygu Tașdelen* \\ Nilgün Doğrusöz** \\ Sorumlu Yazar, *Dr., Anadolu Üniversitesi Devlet Konservatuvarı Müzikoloji Bölümü, \\ e-Mail:duygutasdelen@anadolu.edu.tr, https://orcid.org/0000-0001-5296-2701 \\ **Prof. Dr., ITÜ, TMDK, Müzik Teorisi Bölümü, İstanbul, Türkiye, e-Mail:dogrusozn@itu.edu. \\ tr, https://orcid.org/0000-0003-4818-4075
}

DOI 10.12975/rastmd.2021926 Submitted June 25, 2021 Accepted October 18, 2021

\begin{abstract}
Özet
Rauf Yekta Bey, geç Osmanlı ve erken Cumhuriyet döneminin müzik bilimcisi, teorisyeni ve arșivcisi olarak Osmantı/Türk müziği tarihinde önemli bir konumdadır. Rauf Yekta Bey'in biyografisi ile ilgili -makalemize de öncül olmuș- çeșitli çalıșmalar yapılmıștır. Rauf Yekta Bey'in vefatından sonra, 80 yıldan fazla bir süre araștırmacılara kapalı olan arșivinin açılması ile hem çalıșma yașamına hem de kişisel hayatına dair bilinmeyen yeni veriler ortaya çıkmıştır. Kişisel arşivinin çalışılmasının ardından çıkan belgeler incelendiğinde, Rauf Yekta Bey' in biyografisine eklemeler yapılması ve kendisi ile ilgili bazı anlatıların gözden geçirilerek biyografi inșâsına gereksinim duyulmuştur. Bununla birlikte Bașbakanlık Osmanlı Arșivi'nde bulunan belgeler, dönemin gazetelerinin taranması ve son dönemde yapılan araștırmalar Rauf Yekta Bey'in biyografisinin yeniden yazımını gerekli kılmıștır. Bu makalede, tüm yeni belgeler doğrultusunda Rauf Yekta Bey’in biyografisi yeniden ele alınmıștır.
\end{abstract}

\section{Anahtar Kelimeler}

rauf yekta bey, biyografi, arșiv çalıșması

\section{Giriș}

Osmantı/Türk müzik tarihinde önemli bir yere sahip olan Rauf Yekta Bey'in biyografisi ile ilgili öncül çalıșmalar bulunmaktadır. Rauf Yekta Bey, Paris Konservatuvarı profesörlerinden Albert Lavignac'ın (1846-1916) yönetiminde bir kurul tarafından hazırlanan Encyclopédie de la Musique'in beșinci cildine, Fransizca olarak "Türk Musikisi" maddesini kaleme almıș ve yazı 1922 yılında yayımlanmıștır. $\mathrm{Bu}$ ansiklopedi maddesinin, Orhan Nasuhioğlu tarafından Türkçe çevirisini içeren ve Türk Mûsikîsi başlığıyla yayımlanan kitabın girișinde, Murat Bardakçı tarafından kaleme alınan "Rauf Yektâ Bey'in Hayatı ve Eserleri" bölümü, Rauf Yekta Bey ile ilgili ilk ciddi biyografik çalıșmadır. Kitap 1986 yılında basılmıș olup ${ }^{1}$; Bardakçı kaleme aldığı bölümde, ulaștığı arșiv belgeleri ve kaynaklar doğrultusunda Rauf Yekta Bey'in biyografisini hazırlamıștır.

Rauf Yekta Bey'in biyografisi ile ilgili çalıșan bir bașka araștırmacı ise Süleyman Erguner'dir. Erguner, Rauf Yekta Bey ve Türk Musikisi Üzerindeki Çalışmaları başlıklı doktora tezi ve Rauf Yekta Bey Neyzen-MüzikologBestekâr bașlıklı kitabında Rauf Yekta Bey'in teori çalıșmaları ve eserlerine yoğunlașırken biyografisi ile ilgili bir bölüm de hazırlamıștır.

1965 yılında, Musiki Mecmuası dergisinin 203 nolu Ocak sayısı 'Rauf Yektâ Özel

1 Bardakçı, M. (1986). Rauf Yektâ Bey’in Hayatı ve Eserleri, Türk Mûsikîsi, Rauf Yektâ, (Çev. Orhan Nasuhioğlu), İstanbul: Pan Yayıncılık. 
Sayısı' olarak yayımlanmıștır. Derginin bu sayısındaki yazılar Rauf Yekta Bey'in hayatı ve eserlerine odaklanmıștır.

Bu üç çalıșma dıșında, Rauf Yekta Bey'in yazılarının Latin alfabesine çevirisini içeren tezler, müzik teorisi hakkında yazılar kaleme alınmıș; ancak bu çalıșmalardaki biyografik bilgiler büyük oranda yukarıda bahsedilen üç kaynak üzerinden șekillenmiștir.

\section{Biyografi çalıșmalarında en önemli} kaynaklar șüphesiz ki çalıșılan kișinin kișisel arșivi ve arșivindeki belgeler, mektuplar, fotoğraflar gibi verilerdir. Ancak, Rauf Yekta Bey'in biyografisi ile ilgili önemli bilgileri içermesi öngörülen kișisel arșivi ise uzun yıllar boyunca araștırmacılara kapalı kalmıștır. Rauf Yekta Bey'in koleksiyonu, az sayıda araștırmacının -kısa süreli olarak-görebilme fırsatı bulabildiği ancak muhteviyatı ile ilgili sınırlı bilginin olduğu bir arșivdi. Arșivin içerisindeki Rauf Yekta Bey'in kișisel bilgilerini içeren belgeler ile ilgili ise hiçbir çalıșma yapılamamıștı. 2018 yılında, Nilgün Doğrusöz editörlüğünde yayınlanan Rauf Yekta Bey'in Musiki Antikaları kitabı ile Osmanlı/Türk müziği tarihi bakımından büyük önem tașıyan bu arșiv araștırmacl ve ilgilileri için aydınlanmıștır. Rauf Yekta Bey'in Musiki Antikaları, arșivin seçme kataloğu ve seçilen kataloğun içerikleri hüviyetindedir. Arșivde bulunan belgeler ile Rauf Yekta Bey'in biyografisi, çalıșma hayatı ile ilgili önemli bilgiler de açığa kavușmaktadır.

\section{Kültuir Çevresi, Ailesi ve Çoçukluğu}

Rauf Yekta Bey, doğum adıyla Mehmed Rauf, Sicill-i Ahvâl kaydına² (Ek-1) göre, "bin iki yüz seksen sekiz senesi muharremü'lharâmının beșinde Dersaadet'te", bașka bir deyișle 27 Mart 1871 tarihinde İstanbul'da

2 BOA. DH.SAIDd. 46-285. doğmuștur. Rauf Yekta Bey'in biyografisi üzerine yapılan çalıșmalarda kendisinin Aksaray, Karagöz Mahallesi'ndeki konakta dünyaya geldiği belirtilmektedir. Rauf Yekta Bey'in çocukluk anılarını aktardığı ve ilk bölümleri eksik olan belgede (Ek2), $1294(1877 / 1878)$ yılında yașanan bir yangın olayı sonrası evlerinin müștemilatı ile birlikte yanması nedeniyle "yine Aksaray'da”, “1293'te (1876) emlak edilen köșk"e tașındıklarından bahsedilmektedir. 1294 yılının Zilhicce ayında (Aralık 1877/ Ocak 1878) ise babasının isteği üzerine, belgede “me'vâ-yı kadîmimiz" (eski yurdumuz) olarak bahsettiği Sarıyer'e tașınmıșlardır (Doğrusöz, 2018, 159).

“Harbiye Nezareti Mektubî-i Seraskerî Kalemi birinci mümeyyizi olan babası Ahmed Arif Bey, ilmiye sinifindan Mehmed Emin Efendi'nin, Mehmed Emin Efendi de, Reis'ül küttab vekili Hüseyin Hüsnü Bey'in oğludur. Dergâh-ı muallâ kapıcıbașılarından Abdullah Bey'in oğlu olan Hüseyin Hüsnü Bey'in görevi nedeniyle, Rauf Yekta Bey'in ailesi, eski İstanbul muhitinde Reisülküttabzâdeler şeklinde anılmıștır.

Kapıcıbașı Abdullah Bey'in babası ise, Yeniçeri Ağalığı'ndan 11 Şaban 1178'de (3 Şubat 1765) Kapdan- Deryalığa getirilen ve bir yıl sonra azledilen Ağa Hüseyin Hüsnü Pașa'dır." (Bardakçı, 1986, 8)

Annesini 3-4 yaşlarındayken yaylı arabanın okunun göğsüne girmesi ile babasını ise yedi ${ }^{3}$ yașında çiçek

3 Erguner, Rauf Yekta Bey'in babasının ölüm tarihini 1888 yılı olarak vermiștir ancak bu bilgi babasını 7 yaşındayken kaybettiği bilgisi ile çelișmektedir. Yapılan araștırma sonucunda Ahmed Arif Bey'in ölüm tarihine ulașılamamıștır. Bununla birlikte 1878 yılına ait çocukluk anılarında babasının hayatta olduğu anlașılmaktadır. Ölüm nedeni olarak bilinen çiçek hastalığının İstanbul'daki salgınları araștırıldığında ise dönemdeki en 
hastalığından kaybetmiștir (Erguner, 2003,15; Bardakçı,1986, 8). Küçük yașta ailesini kaybetmesiyle vasiliğini o dönem İstanbul'unun önemli zengin ailelerinde biri olan Altunizade ailesi üstlenmiștir. Buzpınar ve Baltacıoğlu, Altunizade ailesi için altın ișiyle uğrașan, mahlasları II. Mahmut (1785-1839) tarafından verilmiş ve 0 dönemde yaptıkları hayır ișleriyle de anılan bir aile olduğu bilgisini vermektedir (Buzpınar, 2006, 488; Baltacıoğlu, 2000, 8). Kaynaklarda verilen bilgiler doğrultusunda, Rauf Yekta Bey'in hem doğup büyüdüğü ailesinin hem de vasiliğini üstlenen ailenin maddi açıdan varlıklı, saraya yakın ve yer yer bürokrasinin içinde aileler olduğu sonucuna varabiliriz.

\section{Eğitimi ve Divan-1 Hümâyun Dönemi} Rauf Yekta Bey'in arșivinde bulunan ve 6-7 yaşlarında iken hatıralarını kaydettiği metindeki 1877 yılındaki anıları, o dönemde okuduğu okulla ilgili bazı bilgiler içermektedir ${ }^{4}$. Arșivde metnin tamamı bulunmadığı, 8-13. sayfaları bulunabildiği için ilk bahsettiği okulun adı belirsizdir. Okulundan 'müfiz-i aziz' olarak bahseden Yekta, Aksaray'dan Sarıyer'e tașındıktan sonra da bu okula devam ettiğini ve bu iki bölge arasındaki mesafenin uzaklığından dolayı yașadığı zorluğu anılarında “... mekteb-i mezkura devam ediyor idi isem de her gün Aksaray gibi bir mahalden Boğaziçi'nin müntehası olan mahalle gidebilmek için büyük müșkülata uğruyor idim." (Doğrusöz, 2018, 159) şeklinde aktarmaktadır. Bu okulda birlikte okuduğu ve on dört-on beș yıl sonra karșılaștığı arkadașlarının

büyük salgının 1877-78 Osmanlı-Rus Savașı'ndan kaçıp İstanbul'a gelenler nedeniyle bașladığı öğrenilmektedir. 4 Bahsi geçen anıların 2 sayfası Rauf Yekta Bey'in Musiki Antikaları kitabında yayımlanmıștır. Anıların tamamı arșiv çalıșması esnasında Celal Volkan Kaya tarafından çevrilmiştir. isimleri anılarında Numune-i Terakki muallimlerinden Hafız Cemal Efendi, üçüncü Daire ketebesinden Galip Efendi, Mekteb-i Mülkiye mezunlarından Ali Efendi, Tarik-i Aliye'den Tahsin Efendi, Bahriye zabitlerinden Baki Efendi ve Udi Asaf Efendi olarak sıralamıștır. Bu okulun ismi, anılarında yer almasa da Aksaray civarında, Rauf Yekta Bey'e feyz veren bir okul olduğu açıktır. Bu okuldaki derslerinin uzaması nedeniyle, eve geç kalınca babasının kendisini bu okuldan aldığı da yine çocukluk anılarında aktarılmaktadır. Okuldan alınması ile üzüntüsünü șu sözlerle aktarmıștır:

“Bu söz üzerine asabım gevșeyip düșmek derecelerine geldim $\mathrm{ki}$ bu benim için pek tabii idi. Çünkü, bir defa sınıfımın birincisi olup hocalarım evlatları gibi severler idi. Sâniyen çocuklukla beraber arkadaşlarımın teveccüh ve muhabbetlerine mazhar idim. Sâlisen imtihanda mükafat almış olup esna-yı harikte muhrak olan saat bana en büyük bir burhan-1 șeref olduğundan imtihanda yine mükafata nail olmak ümidi șevkbahş ihtar olmuş idi. Rabien söz almakta olduğumuz iki yüz kurușla beraber sultan efendimiz hazretlerinin nail-i iltifatı olmak arzusuna tamamen mağlup idim. Hâmisen ilahici bașı olduğumuzdan eâlîye mahsus mektep cemiyetleri için sokakta ve mektepte arkadașlara bir șevk-i tabii ile kumanda etmeyi pek severdim. Pederimin 'Artık mektebe gitmeyeceksin' sözü üzerine işte bunların cümlesinden mahrum olacağım için değil titremek başımı yerden yere vursam izale-i ye's edemeyecek idim."

Üzüntüsünü anlatmak için yazılan bu cümlelerde okul hayatı ile ilgili bilgiler de saklıdır. Sınıf birincisi olduğu, hatta bu bașarısının ödüllendirildiği, hocaları 
ve arkadașları tarafından çok sevildiği, bu yıllarda ilahicibașı olduğu ve bu görevi mutlulukla sürdüğü anlașılmaktadır.

$\mathrm{Bu}$ okulun ardından babasının isteği ile Fransızca ve Ermenice öğrenmek üzere "doksan beș senesi cemazeyilevvelinde" (Mayıs, 1878 tarihinde) Büyükdere'deki Ermeni mektebine kaydolmuștur. Çocukluk anılarından, Fransızcayı daha zor bulduğu ve çocukça bir hevesle, arkadașları ile sosyalleșebilmek için Ermeniceye meyl ettiği anlașılmaktadır. - 0 dönemdeki ismiyle- Mehmed Rauf'un okul arkadașlarının hemen hemen hepsi Ermeni olduğundan tatil zamanlarında onlarla anlaşabilmek için bu lisana daha hevesli çalıștığı ve Ermenicedeki bașarısının Ermeni arkadaşları tarafından bile kıskanıldığı anılarında aktarılmaktadır. Altı ayda Ermeniceyi Ermeniler kadar iyi konuștuğunu aktaran Yekta, bu dildeki bașarısı ile 'baryo' [zikr-i cemil/bașarı belgesi] almaya hak kazanmıs ve babası bu bașarısını büyük bir sevinçle karșılamıștır. Rauf Yekta Bey babasının yaşadığı mutluluğu şöyle aktarmıștır:

Gelelim pedere: Eve baryoyu getirdiğim zaman sevincinden hüngür hüngür ağlıyor ve bana karșı: “Oğlum! Sen benim ahir zamanıma yetiștin. Sana hiçbir mükafat edemedim. Söyle! Çocukluğunla beraber ne istersen onu söyle! Ifa edeyim" diyerek muttasıl söyleniyor idi. Pederimin bu kelamına mukabil ben de mecmuu yirmi yedi kıtadan ibaret olan kitaplarımın teclid edilmesini rica ettim. Ertesi gün peder kitapları İstanbul'a götürdü. Haftasına cümlesi yaldızlı, cicili bicili yapılmış olarak geldi. (Doğrusöz, 2018, XIV-XV)

Mehmed Rauf'un bu isteğinden, kitaplara olan merakının çocukluk yıllarına uzandığını da söyleyebiliriz. Ermenicedeki bașarısı arkadaşlarının yanı sıra Büyükdere'de yașayan Ermenilerin de takdirini toplamıștır. Bu durumla ilgili "Iște o zamanlar Büyükdere ahalisi ve esnafı nezdinde şöhretim Ermenice bilmekliğimden ve Sarıyer ahalisi indindeki mergubiyetim [kıymetim] dahi güzel sesimden hasıl olmuștu." yazmıștır. Anılarında sesi ile ilgili "güzel, tiz, muharrık [yakan]" olduğu bilgisini vermiștir.

Rauf Yekta Bey'in bu anıları, çoçukluğunun çokkültürlü ve birden fazla dilin konușulduğu bir sosyalleșme alanında geçtiğini göstermektedir. Anılarından öğrenmeye meraklı, farklı dilleri ve kültürleri bilmeye hevesli, bașarılı, liderlik yapmayı seven, disiplinli, özverili ve takdir gördükçe daha fazla çalıșan bir çocuk olduğu anlașılmaktadır.

Rauf Yekta Bey'in Murat Bardakçı tarafından hazırlanmıș biyografisine göre ise Rauf Yekta Bey, Simkeșhâne İbtidâîsi bitirmiștir. Sicill-i Ahval kaydına göre "Mahmûdiye Rüșdiyesiyle lisân mektebinde müretteb dersleri tahsîl ve ikmâl ederek iki kıt'a șehâdetnâme almıștır” Bardakçı, Rüșdiye’yi bitirdiği tarihi 15 Temmuz 1300 (28 Temmuz 1884) olarak aktarmıștır. Sicill-i Ahval kaydına göre Mahmudiye Rüșdiyesi'ni bitirdikten sonra, "Bin üç yüz bir senesi şevvalinin on üçünde [6 Ağustos 1884] pederinden müntakil on iki bin beș yüz kuruș bedelli ze 'âmetle Divan- ו Hümâyun kalemine" girmiștir. Rauf Yekta Bey'in biyografisini anlatan çalıșmalarda 12.500 kuruşluk gelirin 'dedesinden' geldiği belirtilmektedir. Ancak Sicill-i Ahval kaydına göre iș, babasından kendisine intikal etmiștir. Babasının ve dedesinin bilgileri incelendiğinde de dedesinin ilmiye, babasının ise kalemiye sınıfından 
olduğu görülmektedir. Bu nedenle Divan-1 Hümâyun'daki iși, babasının ișinin devamı niteliğinde olduğundan, kendisine dedesinden değil babasından geçmiş olduğu düșünülebilir. Illk görevi, kâtip yardımcılığıdır. ${ }^{5}$ Fransızca öğrenimi için Lisan Mekteb-i Âlîsi'ne de kaydolarak, çok iyi derecede Fransızca öğrenir ve dört yıl sonra diploma alır. Arșivinde bulunan Fransizca diploması 1899 tarihlidir (Doğrusöz, 2018, 157). Cocukluk yıllarından itibaren aldığı Fransızca eğitiminin süreklilik gösterdiği açıktır.

1894 yllında, Hasan Pașa isminde Halep'teki bir yönetici tarafından kitabet ve yazısının beğenilmesi sebebiyle Halep'e çağrılır ve 14 Temmuz 1984 tarihinde gemi ile İstanbul'dan ayrılır. ${ }^{6}$

Halep'te hattatlık da öğrenir ancak çok kısa bir süre sonra geri dönerek, Divan-1 Hümâyun'daki görevine devam eder. Hattatlığı nedeni ile 'Yekta' mahlasını almıștır. 1885 yılından 1922 yılına kadar Divan-1 Hümâyun'da çeșitli görevlerde bulunur ve 1922 yılında buradan emekli olur.

Divan-1 Hümâyun'da çalıștığı yıllarda resmî izinler ile müzik alanında çalıșmalar sürdürdügüi 29 Haziran 1914 tarihinde Istılahat Encümeni'nde musiki istılahatı, 2 Haziran 1917 tarihinde mehterhane ve askeri bandolardaki incesaz takımları ile ilgili olarak görevlendirilmiş olduğu arșivinden çıkan belgelerden anlașılmaktadır (Doğrusöz, 2018, 160161). Bununla birlikte, 1901 yılında, ünlü bir Benedikten papazının evini ziyareti

5 Divan- Hümâyun'daki görevleri için bknz: Sicill-i Ahval Defter Kaydı. Rauf Yekta Bey'in hayatının kronolojik listesi için bknz: Ek-3.

6 Halep'e gitmek üzere bindiği gemide yazdığı, gemide ve İzmir'de yașadıklarını anlattıkları günlüğün çevirisi için bknz. Paçacı, G. (2012). Rauf Yekta Bey'in Gezi Günlüğünün Tıpkıbasımı ve Çevrimyazısı, Musikișinas, $12,18-40$. sırasında kütüphanesinden etkilenmesini "Bunları görenler bu memlekette bir konservatuar var da siz de onun müdürü bulunuyorsunuz zanneder! Halbuki o zaman memleketim beni Bâb-ı Âli'de hükümet fermanlarının yazıldığı kalemde çalıștırıyordu." (Sürelsan, 1970, 4) șeklinde anlatır. Dolayısıyla, Divan-1 Hümâyun'da çalıștığı dönemde de Türk müziği ile ilgili çalıșmalarını sürdürdüğü ve bu alanda bir resmî görev ve simgesel sermaye sahibi olma isteği içinde olduğu anlașılmaktadır. Bu yıllarda Yekta, resmî görevle müzik alanında bir kurumda çalıșmasa da; İkbal, Șehbal, Âtî Gazetesi gibi dönemin süreli yayınlarında müzik ile ilgili biyografi, müzik tarihi ve müzik teorisi gibi konularda yazılar yazmaktaydı.

Bu süreli yayınlardaki yazılarının yanı sıra en önemli yazılarından biri olan Encyclopédie de la Musique'in beșinci cildinde yayımlanan "Türk Musiki" maddesini de bu yıllarda yazmıștır. Nasuhioğlu, çevirisini yaptığı maddenin önsözünde, Rauf Yekta Bey'in bu maddeyi 1913 tarihinde kaleme aldığını aktarmaktadır (Yekta, 1986, 7). Ancak Rauf Yekta Bey'in arşivinde bulunan A. Lavignac ile mektuplașmaları 1909 yılına dayanmaktadır (Doğrusöz, 2018, 171172). 22 Aralık 1909 tarihli mektupta, A. Lavignac yazılacak yazının detayları hakkında bilgivermiş; 23 Mayıs 1910 tarihli mektupta ise yazının son gönderilme tarihinin 1 Temmuz olduğunu hatırlatıp, yașanacak bir gecikmenin kendilerini zor duruma düșüreceğini aktarmıștır. Bu mektuba Rauf Yekta Bey tarafından, cevaben yazılan müsvedde mektupta, o dönemde İstanbul'da yaşanan kızamık salgını nedeniyle kendisinin, eşinin ve iki çocuğunun kızamığa yakalandığı, bu nedenle de istenilen tarihte yazıyı yetiștiremeyeceği için 1 Eylül'e 
kadar süre talep ettiği yazılmıștır. Bu mektubu yazdığı dönemde halen Divan-ı Hümâyun'da çalıșan Yekta, -hastalığın yanı sıra- bürodaki işlerinin zamanının çoğunu aldığından, hatta yazısını yazmak için yirmi dört saat içinden ancak yarım saat zaman bulabildiğinden yakınmıștır. Bu denli zor șartlar altında yazılan "Türk Musikisi" maddesi, Türk müziği tarihi ve teorisini, Batılılara anlatmayı hedefleyen bir yayındır. "Türk Musikisi" maddesi hem Batılı anlamda bilimsel bir anlatım sunması hem de Rauf Yekta Bey'in uluslararası temsiliyeti bakımından önem arz etmektedir.

Müzik alanında Zekai Dede, Șeyh Ataullah Efendi, Şeyh Celaleddin Efendi, Ali Efendi, Neyzen Cemal Dede gibi isimlerle çalıșmıștır7 (Erguner, 2003, 22).

\section{Darülelhan Dönemi}

Çeșitli yazılı kaynaklarda Rauf Yekta Bey'in, ilk dönemdeki kurumsal yapı içinde yer aldığı bilgisi tekrarlanmaktadır. Ancak, bilgiler ıșığında, Rauf Yekta Bey, 1922 yılına kadar Divan-ı Hümâyun'da çeșitli görevlerde bulunmuş ve buradan emekli olmasının ardından, Darülelhan'ın ikinci dönemi olarak nitelendirilebilecek yapılanmasında bu kurumda ders vermeye bașlamıștır. Darülelhan'ın ilk dönemi ile ilgili yazdığı yazıların Darülelhan'a dıșarıdan bir bakıșla ve eleștirel olarak yazıldığı görülmektedir.

Rauf Yekta Bey, kurumun ikinci yapılanma döneminde Şark Musikisi Nazariyat ve Tarihi derslerinin yürütücüsü olarak kadroya dahil olmuștur. Aynı zamanda Darülelhan

7 Rauf Yekta Bey'in bestecilik alanındaki çalıșmaları için bknz: Tașdelen, D. Doğrusöz N. Ergur, E. (2021). Gelenek, Değișme, Arayıș: Rauf Yekta Bey’in Besteciliğinde Geleneği Sahipleniș ve Deneysel Yönelim. Osmanlı-Türk Müziğine Bakıșlar: Tarih, Teori ve İcra. Ed: Fikret Karakaya. İstanbul: Arkeoloji ve Sanat Yayınları.
Mecmuası'nda yazıları yayımlanan Yekta, bu dergide kurumun bu dönemi ile ilgili olumlu görüșlerini bildirmiștir.

1926 yılında, Darülelhan'da Șark musikisi șubesi kapatılmıș ve Türk müziği, talimatname ile çalıșma koșulları belirlenen 'Tasnif ve Tespit Heyeti'nin faaliyetleri ile sınırlandırılmıștır. Tasnif ve Tespit Heyeti'nin reisi olarak da Rauf Yekta Bey görevlendirilmiștir.

Rauf Yekta Bey'in arşivinde, kurumdan Türk müziği eğitiminin kaldırılması üzerine, Mustafa Kemal Atatürk'e hitaben yazılan ve alınan bu karardan bir an önce vazgeçilmesi gerekliliği vurgulayan bir mektup müsveddesine rastlanmıștır. Mektupta;

“ Türkiye Reis-i Cumhuru Gazi Mustafa Kemal Pașa Hazretleri'ne

Türk milletinin yetiștirdiği Farabi ve Ibn-i Sina gibi hukema tarafından nazari temelleri kurulan ve garbin vakıf-ı ahval musiki alimleri nezdinde ciddi bir kıymet-i aliyye ve tarihiyyesi olan Türk musikisinin Darülelhan'da tedris edilmemesi hakkında mahza şahsi ihtiraslar sevkiyle (sabık müdür Süreyya Bey tarafından) Sanayi-i Nefise encümenince ittihaz ettirilmek istenilen verilen kararın beynelmilel musiki tarihlerinde siddetle tenkit edilecek bir hadise olacağını kemal-i ihlas ile temin eder ve (asri prensipleri almak suretiyle her türlü tekemmülata müstaid ..... ve milli harsımızın tarihinde aleyhimize tarihi kalacak böyle bir kararın) Maarif Vekaleti'nce mevkii-i icraya konulmaması için her hususta milletimize doğru yolu gösteren büyük ve mukaddes Gazimizin atabe-i șevketine ilticaya mecburiyet 
gördügümüzü arz ile beraber bu hususta șerefsadır olacak irade-i celileleriyle kuvve-i maneviyeleri kırılmış olan muallim ve talebe kullarının ihya ve tebșir buyurulmasını bilhassa istirhama mübasaret eyleriz ferman.

Darülelhan Türk Musikisi Muallimleri Namına” (Doğrusöz, 2018, 185) yazmaktadır.

Rauf Yekta Bey, Vakit'te yazdığı "Nâmık İsmail Bey'e Cevap" yazısında ve Yenises Gazetesi'ndeyayınlanan “GarpçılaraȘiddetli Bir Hücûm” mülakatında, Darülelhan'ın Türk müziği șubesinin kapatılması ile ilgili kararın tebliği gerçekleșmemișken, Sanayi-i Nefise Encümeni üyelerinin Türk müziği ile ilgili fikirlerine sert açıklamalarla cevap vermiștir.

Belirtilen talimatnamenin üzerindeki tarih 9 Aralık 1926'dır. Rauf Yekta'nın Vakit'te yazdığı "Nâmık İsmail Bey'e Cevap" yazısının tarihi 9 Ekim 1926, verdiği mülakatın yayın tarihi ise 3 Ekim 1926'dır. Sanayi-i Nefise Encümeni üyeleri ile bu tartıșmaların bașladığı süreçte Rauf Yekta Bey kurumla ilgili sıkıntıları öngörmüș olacak ki Mısır'da bulunan Kahire Doğu Müzikleri Araștırmaları Enstitüsü'ne hocalık bașvurusunda bulunmuștur. Yazıșmalar 6 Ekim 1926 tarihinde bașlamıș, 1927 yılında da devam etmiș ancak yapılan yazıșmanın sonucu hakkında arșivde herhangi bir belgeye ulașilamamıștır (BOA, HR.iM.205.43; Karaduman, 2013, 476).

\section{Darülelhan Sonrası Çabalar: Görev Aldığı Cemiyetler, Kurullar}

Darülelhan'ın, -daha önce belirtilen9 Aralık 1926 tarihinde Sark musikisi șubesinin kapanmasının ardından, Rauf Yekta Bey, Muallim İsmail Hakkı ve Zekâizade Hafız Ahmet ile birlikte Tasnif ve Tespit Heyeti'nde Türk müziğini kayıt altına alma misyonunu üstlenmișlerdir. Bu görevin yanı sıra, 1926 yılı sonrasında kitap yazma ve istinsah çalıșmalarının hızlandığı da görülmektedir. Ayrıca Türk Ocağı'nda konser çalıșmaları sürdürdükleri de bilinmektedir.

Yapılan arşiv çalıșması ile Rauf Yekta Bey'in farklı görev ve çalıșmalarının bulunduğu görülmüștür.

Darülelhan'ın kapatılan Şark musikisi şubesinden bir grup öğrenci tarafından kurulan Halk Musiki Cemiyeti'nin idare heyetinin reisliğini yapmıștır (Bknz. Belge-1). Basında çıkan haberlerde, cemiyetin azalarının serbest meslek sahibi, ișlerinde bașarılı olmuş gençlerden oluștuğu belirtiliyor. Cemiyet aracılığı ile, Halk müziği eserlerinin ağırlıklı olduğu konserler düzenlendiği ve yıllık cemiyet toplantısı düzenlendiği anlaşılmaktadır.

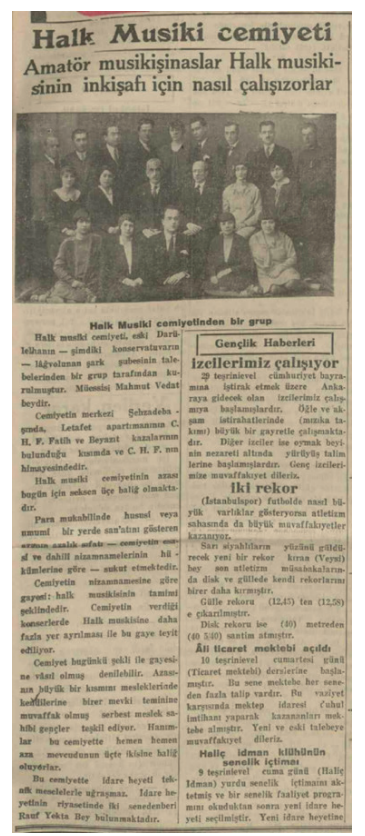

Belge 1. Vakit Gazetesi, 12 Ekim 1931 tarihli Halk Musiki Cemiyeti ile ilgili Haber. 
1932 yılında Halkevi güzel sanatlar șubesinin müzik komisyonunda yer almıștır (Bknz. Belge 2). 19 Şubat 1932 tarihli Vakit gazetesinde, o gün Türkiye'nin 19 şehrinde birden Halkevlerinin açılacağı bilgisi verilmiștir. 5 Mart tarihinde de Halkevlerinin güzel sanatlar şubesi ile ilgili bir toplantı düzenlenmiștir. Bu toplantıda müzik şubesinin üyesi olarak yer alan Rauf Yekta Bey, komisyonda Seyfettin Asaf, Cemal Reșit, Hasan Ferid ${ }^{8}$ gibi isimlerle birlikte çalıșmıș ve diğer sanat dallarından önemli sanatçıların bir araya geldikleri komisyonlarla birlikte Halkevlerinin güzel sanatlar alanındaki eğitimi ve gelișimi ile ilgili fikir vermişlerdir.

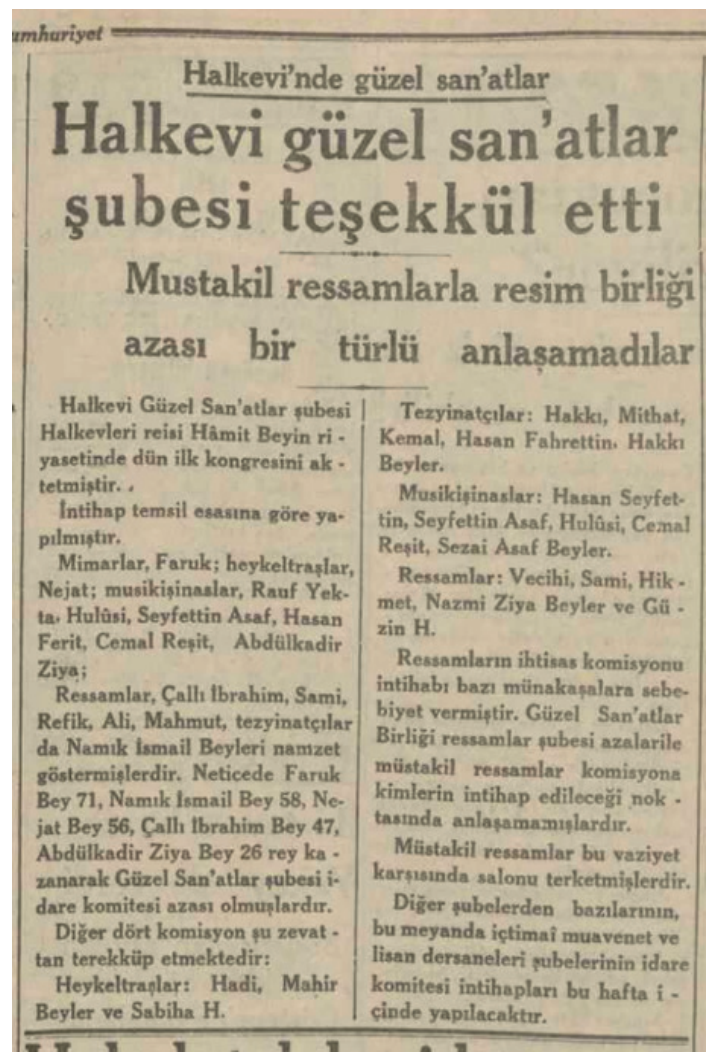

Belge 2. Halkevleri ile Ilgili Haber

8 Ayr. bilgi için bknz: Berkman, E. Taşdelen, D. (Yay. Haz.) (2021). 40. Vefat Yilında Hasan Ferid Alnar. Eskișehir: Anadolu Üniversitesi Yayınları.
21 Kasım 1932 tarihli Vakit Gazetesinde, Türk Dili Tetkik Cemiyeti'nin pek çok bilim alanında terminoloji oluşturabilmek için heyetler oluşturduğu görülmektedir. Rauf Yekta Bey, bediiyat ve güzel sanatlar alanının musiki ve raks şubesi için Ali Rifat Çağatay, Ekrem Zeki Üngör, Mesut Cemil Bey, Mahmut Ragıp Gazimihal ve Muallim İsmail Hakkı Bey gibi isimlerle birlikte seçilmiștir9

Beylerbeyi Musiki Cemiyeti'ni çalıștırdığı, 1931 yılında düzenlenen Türkiye Bülbülü isimli ses yarıșmasında hakem heyetinde bulunduğu ve çeșitli cemiyetlerin kurulmasında da yardımcl olduğu dönemin gazete haberlerinden öğrenilmektedir.

\section{Kahire Kongresi}

Kahire Kongresi, Rauf Yekta Bey'in uluslararası temsiliyeti bakımından büyük önem tașımaktadır. Kral Fuad'ın isteği ile gerçekleșen kongre, 1932 yılında Kahire'de düzenlenmiștir. Kahire Kongresi ile ilgili haberler, dönemin gazetelerinde de çokça yer almıștır. Bu haberlerden, kongrenin hazırlıklarının 1930 yılında bașladığı anlașılmaktadır (Bknz. Belge 3). 18 Temmuz 1930 tarihli, "Şark Musikisi" bașlıklı haberde, bu kongre için konservatuvara davetli listesi ile ilgili bir talepte bulunulduğu ancak konservatuvarın Batı müziği ile uğraștığından katılım olmayacağı ve Rauf Yekta Bey'in isminin bildirileceği aktarılmıștır (Vakit, 1930, 5). Bildirilen isimlerden, Mısır konservatuvarının seçtiği kişiler davetli olarak kongreye katılacaklardır. Rauf Yekta Bey, 1931 yılında George Farmer ile mektuplașmalarında kongereye aldığı 9 Dönemin terminoloji meselesi ile ilgili bknz: Doğrusöz, N. (2018). Hüseyin Sadeddin Arel'in Kaleminden Musiki Terimleri Meselesi, 2017 Arel Sempozyumu Bildirileri. İstanbul: Türkiyat Araștırmaları Enstitüsü. 
davetten bahsetmekte, Farmer'dan talep edeceği ücret hakkında fikir almaktadır (Katz, 2015,135).

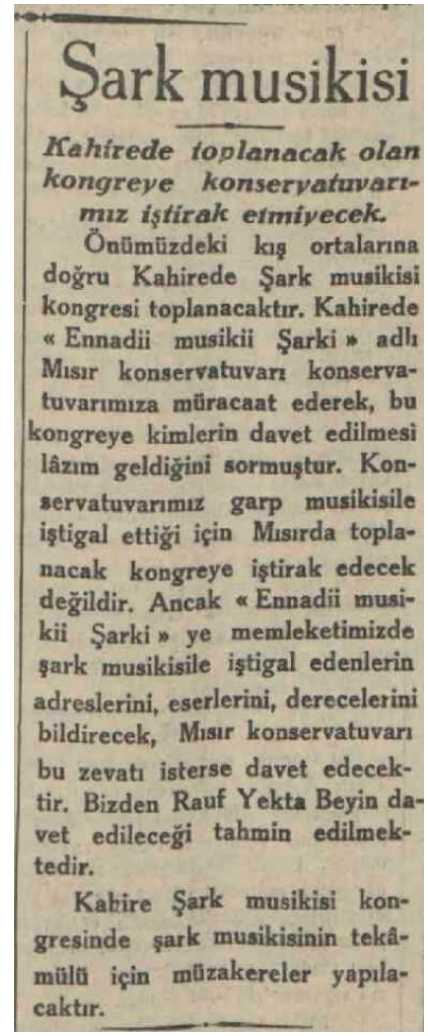

Belge 3. Vakit Gazetesi, 18 Temmuz 1930, 5.

Rauf Yekta Bey, Türkiye'den seçilen diğer katılımcı Mesud Cemil Bey ile 8 Mart 1932 tarihinde Kahire'ye yola çıkmışlardır ${ }^{10}$. Bu kongrede Rauf Yekta Bey'in ismi, üç komisyonda geçmektedir. Bunlardan biri Müzik Eğitimi komisyonu, diğeri Müzik Dizisi (L' échelle Musicale) Komisyonu ve üçüncüsü ritmlerin ve kompozisyonun biçimleri (Modes des Rythmes Et De La Composition) komisyonudur. Üçüncü komisyonda bașkanlık görevini üstlenmiștir ${ }^{11}$.

10 Yolculuk ve kongre sırasında tuttuğu notların çevirisi İsmail Baha Sürelsan tarafından yapılmıș; Musiki ve Nota Dergisi ve musikidergisi. net sayfasında yayımlanmıștır.

11 Kongredeki komisyonlar ve komisyonlardaki kișiler için bknz: Katz, I. J. (2015). Henry George Farmer and the First International Congress of Arab Music (Cairo 1932).
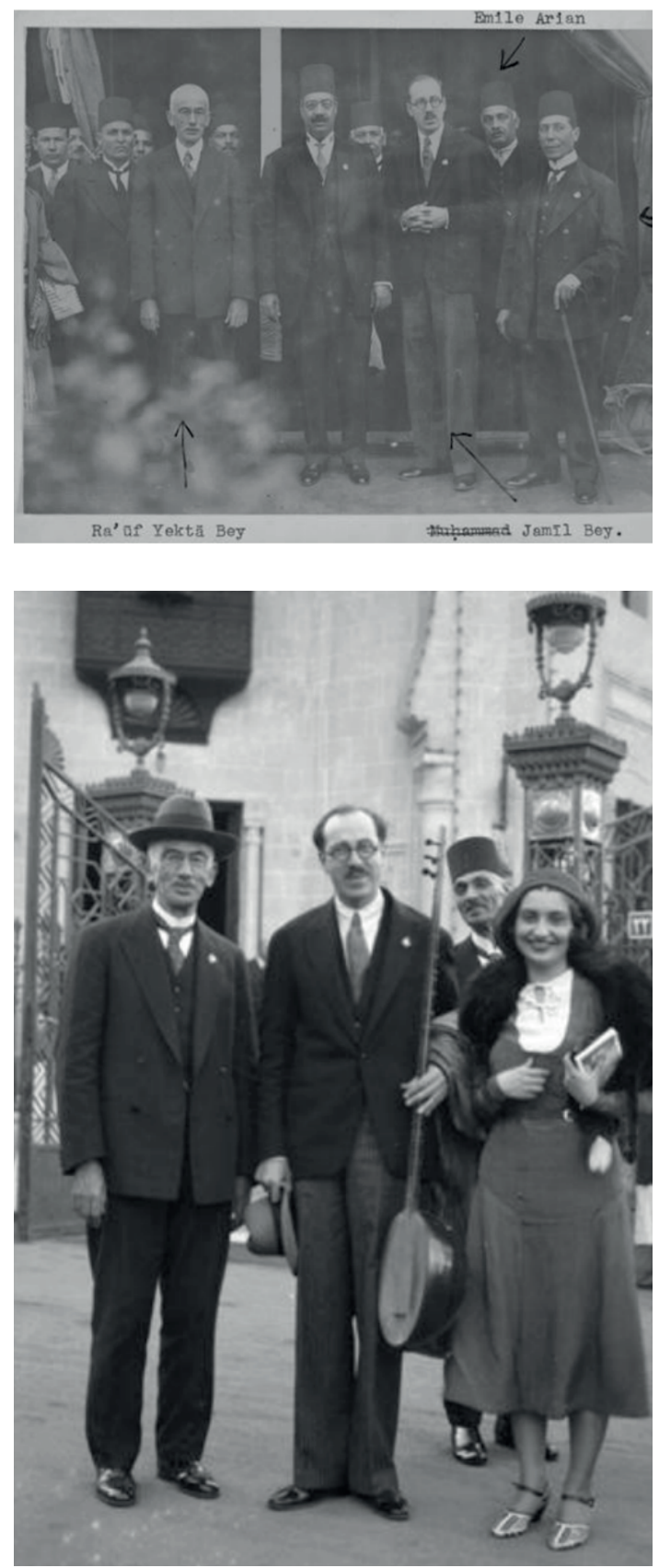

Belge 4. Kahire Kongresi'nden Fotoğraflar. ${ }^{12}$

\section{Vefatı}

9 Ocak 1935'te Beylerbeyi'ndeki evinde hayatını kaybetmiștir.

12 Görsellin alındığı kaynak için bknz: Katz, I. J. (2015). Henry George Farmer and the First International Congress of Arab Music (Cairo 1932). 

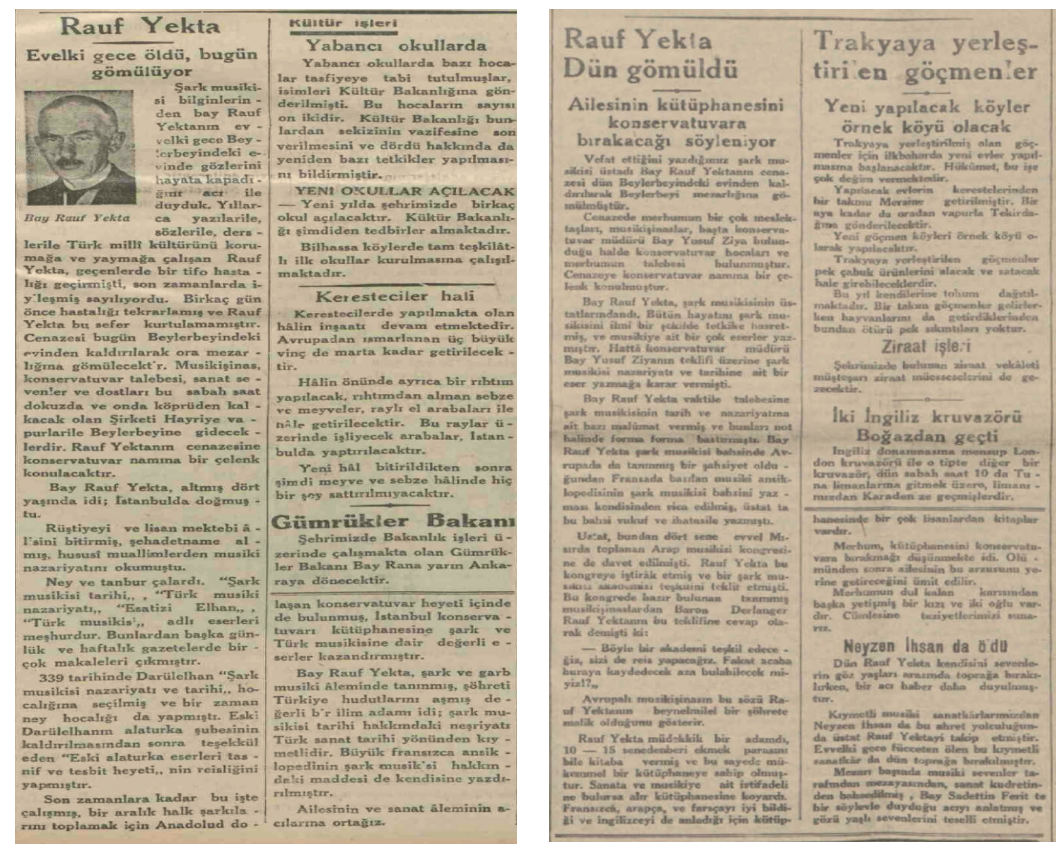

Belge 5. Kurun ve Milliyet Gazetelerinin Rauf Yekta Bey’in vefatı ile ilgili yayımladığı haberler.

\section{Sonuç}

Döneminin önemli düșün ve yazın aktörlerinden biri olan Rauf Yekta Bey ile ilgili biyografi çalıșmaları uzun zaman önce hazırlanmıștır. Şu an eldeki belgeler ve kaynaklar, yapılmıș çalıșmaların ötesinde bilgiler sunmaktadır. Araștırmacılara açılan Rauf Yekta Bey'in kișisel arșivi, Bașbakanlık Osmanlı Arșivi'nde bulunan belgeler, dönemin süreli yayınlarının taranması ile Rauf Yekta Bey'in biyografisinin yeniden inșâsının gerekliliği doğmuștur. Bu çalıșmada elde edilen yeni belgelere odaklanilmış ve bu belgeler doğrultusunda Rauf Yekta Bey'in hayatı incelenmiștir. Kișisel arşivinden çıkan belgeler Rauf Yekta Bey'in Musiki Antikaları kitabında görselleri ve içerikleri ile sunulsa da bağlam içinde bir biyografi çalıșmasına ilk kez bu makale ile malzeme olușturmuștur.

Otobiyografik anlatımı ile çocukluğu ve büyüdüğü ortam hakkında fikir sahibi olmaktayız. Bu anılardan okulu, çocukluğu ve kültürel çevresi ile ilgili bilgiler edinmekte ve Rauf Yekta Bey'in fikir dünyasının kaynağını da anlamlandırmak için veriler bulmaktayız. 1922 yılına kadar Divan- Hümâyun'daki çalıșma hayatı ile ilgili detaylar, bu iși sürdürürken aynı zamanda Türk müziği ile ilgili üretimini büyük zorluklarla devam ettirmeye çabalaması içinde olduğunu göstermektedir. Arșivindeki belgelerle en önemli çalıșmalarından biri olan "Türk Musiki" maddesinin yazım tarihindeki çelișki giderilmiș, A. Lavignac ile yazıșmalarından maddenin yazım tarihi ve süreci ile bilgi sahibi olunmuștur.

Darülelhan'da çalıștığı yıllarda dönemin Şark ve Garb müziği tartıșmalarında önemli bir pozisyonda bulunup Türk müziğinin en ateșli savunucularından olsa da yașanan sürecin ve kurumdaki sorunların kendisini Mısır'daki konservatuvara başvuru yapmaya ittiği görülmektedir. 
Rauf Yekta Bey'in Darülelhan sonrası çalıșma hayatı ile ilgili Tasnif ve Tespit Heyeti'ndeki görevi ve Türk Ocağı'nda konser çalıșmaları ile ilgili bilgiler kaynaklarda yer almaktadır. Bununla birlikte yazma ve istinsah çalıșmalarının bu dönemde hızlandığı da görülmektedir. $O$ yılların gazete ve süreli yayınlarının taranması ile Rauf Yekta Bey'in yașamının bu dönemi ile ilgili de detaylara ulașılmıștır. 1932 yılında katıldığı Kahire Kongresi ve Rauf Yekta Bey'in bu kongredeki görevleri ile ilgili bilgiler de sunulmuștur.

Öyle anlaşılmaktadır ki, Rauf Yekta Bey'in kişisel arşivinin bütünü araștırmacılara açıldığında ve bu arşivdeki belgeler değerlendirildiğinde Rauf Yekta Bey ile ilgili çok daha detaylı bilgilere ulaşılabilecektir. 


\section{Yazarların Biyografileri}

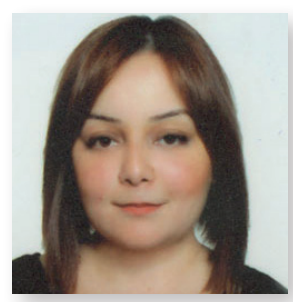

\section{Duygu Tașdelen}

Duygu Taşdelen, İstanbul Teknik Üniversitesi Türk Müziği Devlet Konservatuarı Müzikoloji Bölümü'nden mezun oldu. Yüksek Lisans derecesini ìstanbul Teknik Üniversitesi Sosyal Bilimler Enstitüsü, Türk Müziği programından aldı. Doktorasını İstanbul Teknik Üniversitesi'nde Müzikoloji ve Müzik Teorisi programında tamamladı. 2013 yılından bu yana Anadolu Üniversitesi Müzikoloji Bölümü’nde araștırma görevlisi olarak çalıșmaktadır.

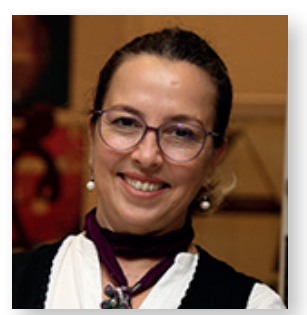

\section{Nilguin Doğrusöz}

İzmir'de doğdu. 1989 yılında İzmir Ege Üniversitesi Türk Müziği Konservatuarı'ndan mezun oldu. İstanbul Teknik Üniversitesi (iTÜ) Sosyal Bilimler Enstitüsü'nden yüksek lisans (1993), sanatta yeterlilik (1997) ve doktora (2008) derecelerini aldı. 2000 yılında New England Conservatory of Music'te (Boston, $A B D$ ) Türk vokal müziğinin spektrografik analizini yaptı. 2001 yılında Harvard Üniversitesi Ortadoğu Araștırmaları Merkezi'nde (CMES) Osmanlı/Türk müziği dersleri vermek üzere misafir öğretim üyesi olarak görev yaptı. Osmanlı/Türk Müziği'nin nota sistemleri, teorisi ve tarihi konularında kitaplar, makaleler ve bildiriler yayınladı. Halen iTÜ Türk Müziği Konservatuarı müzik teorisi bölümünde profesör olarak görev yapmaktadır. 
Kaynakça

BOA. DH.SAIDd. 46-285

BOA, HR.IM.205.43

BOA. DH.SAIDd. 46-285

Baltacioğlu, T. (2000). Altunizade Köșkü’nün Öyküsü. İstanbul: Mim Matbaacılık.

Bardakçı, M. (1986). Rauf Yektâ Bey'in Hayatı ve Eserleri, Türk Mûsikîsi, Rauf Yektâ, (Çev. Orhan Nasuhioğlu), İstanbul: Pan Yayıncılık.

Berkman, E. Taşdelen, D. (Yay. Haz.) (2021). 40. Vefat Yılında Hasan Ferid Alnar. Eskișehir: Anadolu Üniversitesi Yayınları.

Deren, S. (2007). Kültürel Batılılașma, Modern Türkiye'de Siyasal Düșünce Cilt III Modernleșme ve Batıcılık, İstanbul: iletișim, s. 382- 402.

Doğrusöz, N. (ed.) (2018). Rauf Yekta Bey'in Musiki Antikaları. Ankara: Atatürk Kültür Merkezi Bașkanlığı.

Doğrusöz, N. (2018). Hüseyin Sadeddin Arel'in Kaleminden Musiki Terimleri Meselesi. 2017 Arel Sempozyumu Bildirileri. İstanbul: Türkiyat Araștırmaları Enstitüsü.

Erguner, S. (2003). Rauf Yektâ Bey NeyzenMüzikolog-Bestekâr. İstanbul: Kitabevi.

Karaduman, İ. (2013). Ra'uf Yekta Bey'e Dâir Bilinmeyen Birkaç Belge. Tarih Okulu Dergisi. sayı 16, s. 471-487.

Katz, I. J. (2015). Henry George Farmer and the First International Congress of Arab Music (Cairo 1932).

Kurun, 10 Ocak 1935, 3.

Milliyet, 11 Ocak 1935, 3.

Paçacı, G. (2012). Rauf Yekta Bey'in Gezi Günlüğünün Tıpkıbasımı ve Çevrimyazısı. Musikișinas, 12, 18-40.

Tașdelen, D. Doğrusöz N. Ergur, E. (2021). Gelenek, Değișme, Arayıș: Rauf Yekta Bey'in Besteciliğinde Geleneği Sahipleniş ve Deneysel Yönelim. Osmanlı-Türk Müziğine Bakışlar: Tarih, Teori ve İcra. Ed: Fikret Karakaya. İstanbul: Arkeoloji ve Sanat Yayınları.

Vakit Gazetesi, 12 Ekim 1931,5.

Vakit Gazetesi, 18 Temmuz 1930, 5. 


\section{Ekler}

Ek-1. Rauf Yekta Bey’in Sicill-i Ahval Defteri Kaydı

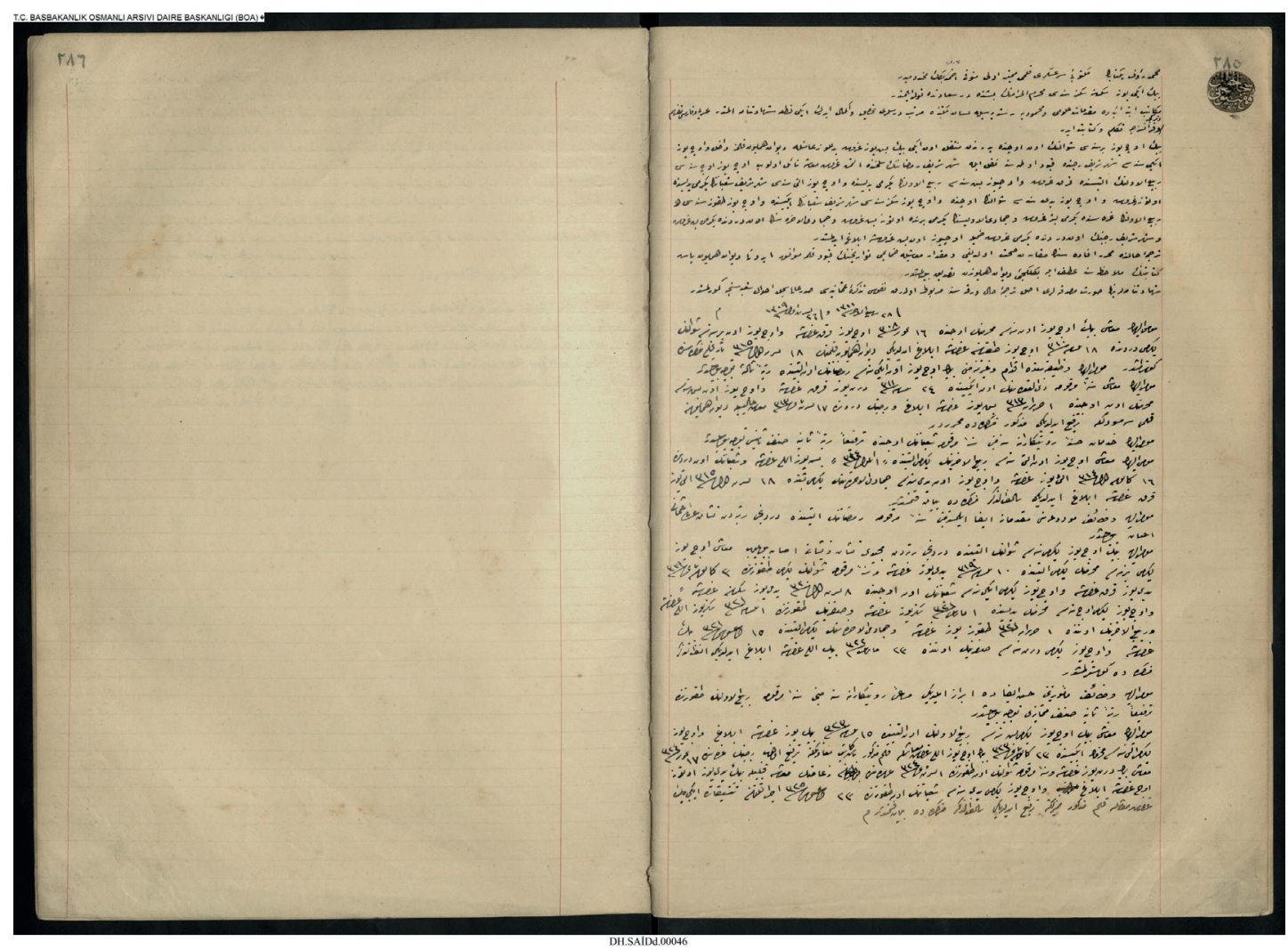


Ek 2. Rauf Yekta Bey'in çocukluk hatıraları

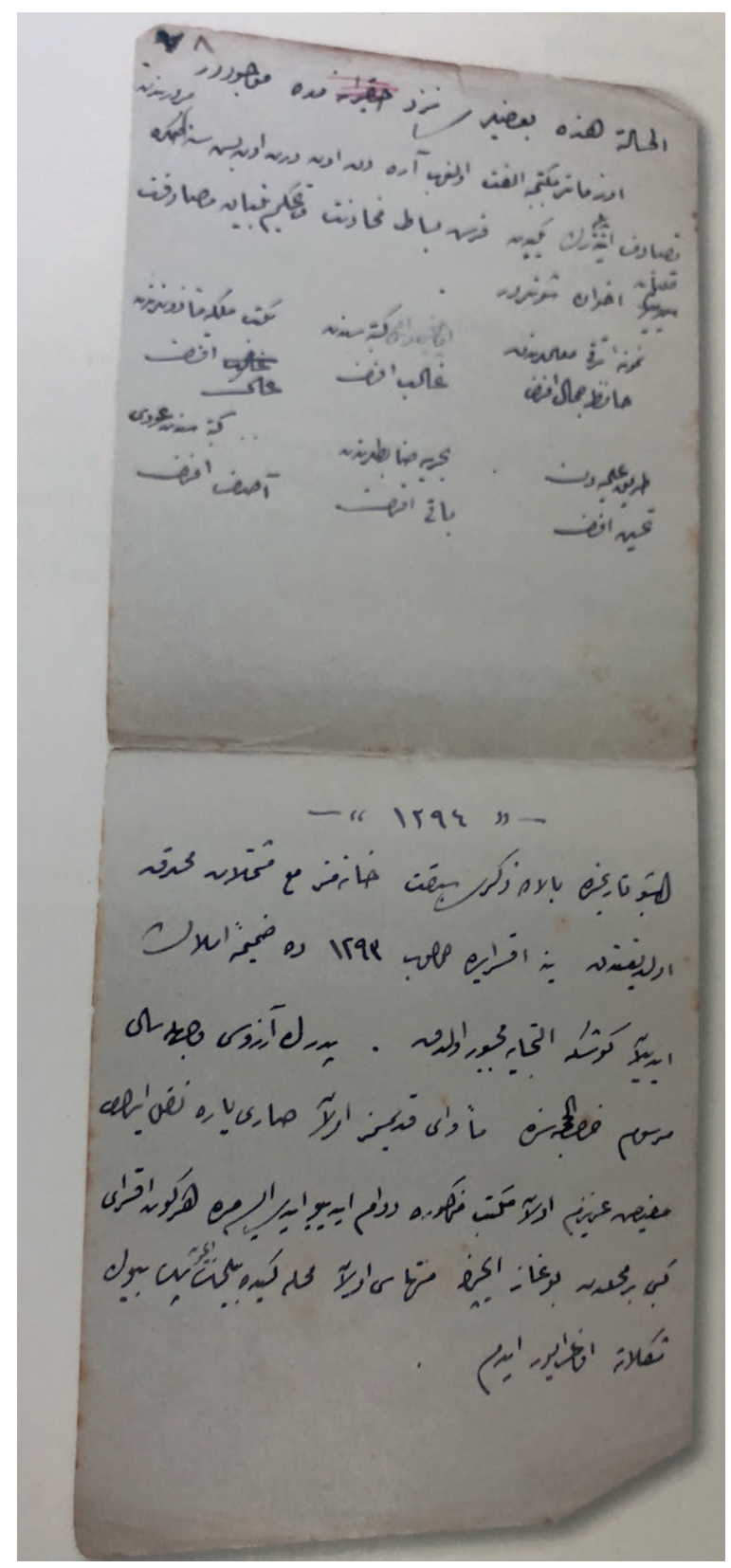


Ek-3. Rauf Yekta Bey'in Hayatının Kronolojik Listesi

\section{TARIHLER RAUF YEKTA BEY KRONOLOJISI}

1871: 27 Mart tarihinde İstanbul'da doğmuştur.

1874: Annesinin vefatı.

1875: Babası Yıldız Hanım'la evlenmiștir.

1877/1878: Aksaray'dan Sarıyer'e taşınmıșlardır.

1878: Büyükdere'deki Ermeni mektebine kaydolmuștur. (Mayıs)

1884: Mahmûdiye Rüștiyesini 1.likle bitirmiștir. (28 Temmuz)

Divan Hümâyûn kaleminde kâtip yardımcısı olarak göreve bașlamıștır. (6 Ağustos) 1885: Zekai Dede ile çalıșmaya bașlamıștır. (2 yıl)

Kayıtlar Odasında çalıșmaya bașlamıştır.

1885 tarihinden önce Hattât Nâsıh Efendi'den hat dersleri almıștır. (Hocanın ölümü 1885.)

1886: Mevlevi tarikatına girdi. Kasımpașa Mevlevihanesi postnişini Ali Efendi'den sikkepûș olmuștur.

Ney üflemeye bașlamıștır.

1887: Șeyh Ataullah Efendi ile çalıșmaya bașlamıștır. (1 yıl)

Șeyh Celaleddin Efendi ile çalıșmaya bașlamıștır. (2 yıl)

1894: Yazı ve hitâbeti beğenildiği için Halep'e çağırılmıș. Halep’e gidip, kısa süre sonra geri dönmüștür.

Şah ney üfleyebilecek düzeyde ney çalmaktadır.

1895: Rütbe-i Salise(binbașı karșılığı) olarak terfi etmișitir.

1897: Divan ו Hümâyûn Kalemi Ser-müsevvidliğine terfi etmiștir.(Kasım)

Rütbe-i saniyyenin sınıf- וânisine (yarbay karșılığı) terfi etmiştir. (Aralık)

1899: Fransızca diploması.

1900: Dördüncü rütbeden nișân- Âlî Osmanî ‘yi almıștır.

1902: Esâtîz-i Elhan'ın I. Ve II. Cüzlerinin yayımlanmamıștır.

1903: Dördüncü rütbeden nîșân-1 mescîdî nîșân-1 zîșânı verilmiștir.

1904: Emced Yektay Doğumu.

1906: İkinci rütbeden mümeyyiz (albay karșılığı) getirilmiștir.

1908: Bașkâtip muavini olur.

1909: Kalemde mümeyyizliğe getirilmiștir.

Fatma Lamiâ Doğumu.

A. Lavignac ile mektuplaşmaları.

1913: Emine Talia Doğumu.

1914: Istılahat Encümeni'nde musiki ıstılahatı alanında görevlendirilmesi. (Haziran) 1917: Ahmed Arif Yektay Doğumu.

Mehterhane ve askeribandolardaki incesaz takımları ile ilgili olarakgörevlendirilmiștir. (Haziran) 
1919: Türk Notası ile Kırâat-ı Mûsikiyye Dersleri.

1922: Beylikçi Muâvini iken emekli olmuştur.

Yenikapı Mevlevihanesi'nde neyzenbașı olmuştur. (Üç yıl)

Türk Mûsikîsi Monografi'nin yayımlanmıștır.

1923: Darülelhan'da ders vermeye bașlamıștır.

Yegah Mevlevi Ayini Yenikapı Mevlevihanesi'nde mukabele edilmiștir.

1924: Türk Mûsikîsi Nazariyatı'nın yayımlanmaya bașlamıștır.

1925: Esâtîz-i Elhan'ın III. Cüzünün yayımlanmıștır.

Şark Mûsikîsi Tarihi'nin yayımlanmıștır.

1926: Kahire Doğu Müzikleri Araștırmaları Enstitüsü’ne hocalık bașvurusu ile ilgili yazıșmalar. (6 Ekim)

Tasnif ve Tespit Heyeti'nde çalıșmaya bașlamıștır.

1932: Halkevi güzel sanatlar șubesinin müzik komisyonunda yer almıștır.

8 Mart Kahire Kongresi'ne gitmiștir.

Türk Dili Tetkik Cemiyeti'nin terminoloji heyetinde görev almıştır.

1934: Mütâlaât ve Erâe Havle Mu'temeri'l-Mûsikkiyyi'l Arabiyye

1935: 8 Ocak vefat etmiştir. 


\section{A new biography of Rauf Yekta Bey in the light of new sources}

\section{Extended Abstract}

Rauf Yekta Bey has an important position in the history of Ottoman/Turkish music as a musicologist, music theorist and archivist of the late Ottoman and early Republican periods. Various studies have been carried out on Rauf Yekta Bey's biography, which was also the precursor to our article. With the opening of the archive of Rauf Yekta Bey, which has been closed to researchers for more than 80 years after his death, new unknown data have emerged regarding both his working life and his personal life. When the documents that came out after the study of his personal archive were examined, it was necessary to make additions to Rauf Yekta Bey's biography and to construct a biography by reviewing some of the narratives. However, the documents in the Prime Ministry Ottoman Archives, the scanning of the newspapers of the period and the recent researches necessitated the rewriting of Rauf Yekta Bey's biography.

The biographical narrative obtained from the archives give us an idea of the environment in which he grew up. These memoirs give information as to his school, family, childhood, and cultural surroundings as well as data to make sense of Rauf Yekta Bey's world of ideas. As can be understood from these memories, Rauf Yekta Bey had a childhood that was keen to learn, eager to know different languages and cultures, successful, loving to lead, disciplined, selfsacrificing and working more as he was appreciated.

Details about his work life in Divan- Hümayun until 1922 show that he strived to continue his production in Turkish music despite challenges while continuing his job. It is understood from correspondences that his work at Divan Hümayun was very time consuming and that he tried to continue his research on Turkish music in what little leisure time he had. The Turkish Music chapter of the Encyclopédie de la Musique, which includes his theory studies, was published during this period of his life. The Turkish Music chapter is significant both in that it presents a scientific narrative as perceived in the West and in relation to Rauf Yekta Bey's international representation.

It is observed that even though he had an important position in the discussions on Eastern and Western music during his employment at Darülelhan and was one of the most fervent advocates of Turkish music, the experienced process and issues at the institution have pushed him to applying to the conservatory in Egypt.

It is known that Rauf Yekta Bey assumed a duty on the Classification and Identification Council and gave concerts at Türk Ocağı after his employment at Darülelhan. It is also observed that his efforts on writing and copying gained impetus during the same period. A review of newspapers and periodicals of the era has yielded details about this particular period in Rauf Yekta Bey's life. Information not available in previous resources was used in an attempt to shed light on this period in his life. Information on his participation at the 1932 Cairo Congress which is an important indicator of international representation and his duties there have also been presented.

In this article, the biography of Rauf Yekta Bey has been reconsidered in line with all the new documents.

Keywords

rauf yekta bey, biography, archive 